\title{
Prospects of Transforming Conventional Commercial Buildings to Net Zero Energy Building - Balancing the Economic Aspects with Energy Patterns
}

\author{
Danyal SHUJA ${ }^{1}$, Syed Shujaa Safdar GARDEZI ${ }^{2 *}$, Muhammad Rashid IDREES ${ }^{3}$ \\ ${ }^{1-3}$ Department of Civil Engineering, Capital University of Science and Technology (CUST), Islamabad \\ Expressway, Kahuta Road, Zone-V 44000 Islamabad, Pakistan
}

\begin{abstract}
Energy crises has been a serious concern for economies especially for developing ones. The building stocks developed through conventional methods pose serious barriers towards sustainable energy consumption patterns. The transformation of such existing facilities into Net Zero Energy Buildings (NZEB) can offer a valuable opportunity to manage the challenging energy loads. However, cost aspect of such transformations remains the key and explored in current study to assess a breakeven point with the energy conservations. Four commercial buildings, three and four story, were selected as case studies. 3D digital models were developed for energy analysis through cloud computing. Comparative analysis for energy consumption patterns was performed in four phases. For conventional approach, the annual consumptions ranged from $310 \mathrm{kWh} / \mathrm{m}^{2} / \mathrm{yr}$ to $563 \mathrm{kWh} / \mathrm{m}^{2} / \mathrm{yr}$. Based upon the local conditions, roof insulation and PV were adopted as NZEB parameters. This resulted a maximum energy saving of $6 \%$. The corresponding cost analysis observed an addition expense of almost $11 \%$ for such incorporation with an average payback period of 4.5 years.
\end{abstract}

Keywords - BIM based energy analysis; causal relationship; conventional construction; cost analysis; Net Zero Energy Building (NZEB) transformation

\section{INTRODUCTION}

Buildings contribute almost $40 \%$ to our carbon footprint and $30 \%$ of global greenhouse gasses $(\mathrm{GHG})$ which is becoming serious considering the global warming and other climatic and geological changes occurring in the world today [1]. According to World Energy Outlook 2021, International Energy Agency [2], the global urbanization is expected to increase up to $68 \%$ by the year 2050. This is expected to result in a tremendous increase in energy demand as of today. The electricity requirements would be a dominant element in such demands with serious environmental concerns in terms of carbon emissions. Cao et al. [3] studied the stateof-the-art technologies for ZEB and reported that the buildings in U.S. and E.U consume $40 \%$ of the total energy and $27.3 \%$ in China. Santamouris [4] presented the framework for present and future energy consumptions required for cooling. The study concluded an increment by $275 \%$ of the current cooling demand for the commercial buildings by 2050 . The study also confirmed that commercial buildings covered around 20 billion square meters in 2010 which is likely to increase up to 80 billion square meters by 2050 . According to a report by Global Energy Review 2019 [5], the carbon emissions related to energy consumption remained stable at 33.2 Gigatons (GT) during the year 2019, following the increases in last two years. This

* Corresponding author.

E-mail address: dr.shujaasafdar@cust.edu.pk 
stability in the carbon emissions is mainly because of the shift of developed economies towards the renewable energy sources such as wind and solar. In the developing economies the $\mathrm{CO}_{2}$ emissions rose by $1.7 \%$ in 2019 which makes these economies account for two third of global $\mathrm{CO}_{2}$ emissions. According to World Bank [6], the total global $\mathrm{CO}_{2}$ emissions has increased by almost $10 \%$ in 2018 as compared to the levels in the year 2000 .

With the ever-increasing demand of energy due to the expansion of urban population, the world requires serious measures to overcome the energy crises. Solutions are required to make sure the sustainable use of the renewable energy resources [7]. The expansion of cities has resulted in the abundance of commercial and residential buildings. Conventional buildings are inefficient and they are the main consumers of electrical energy due to their poor energy efficiency measures. In order to make construction industry more feasible and efficient in terms of economy and its impact on the environment and society, focus should be made on how much energy buildings utilize, how the efficiency of energy utilization can be improved and more importantly buildings capable of generating enough energy to meet their own needs. The concept of 'Net Zero Energy Building' Net-ZEB is about the efficient use and on-site/offsite production of sufficient amount of energy through renewable sources to fulfil its own requirement [8]. Considering the environmental impacts of the conventional building, the significance of the NZEB has become more of an obligation than just a possibility. For achieving net zero energy goals, the transformation of the conventional building to NZEB is inevitable. The principle of NZEB is widely applicable and feasible in building construction. However, the benefits of NZEB are not only limited to efficient energy utilization but also countless environmental and social advantages [9]. According to de Rubeis et al. [10], net zero energy goals in buildings requires transformation of existing methods of energy production and efficiency to make them energy self-sufficient. NZEBs have the potential to bring huge cost saving benefits to the owner and there has been a lot of research being carried out to determine the benefits of Net-ZEB in terms of cost saving.

Kylili and Fokaides [11] studied the contribution of ZEBs in achieving smart cities in Europe and presented that it's possible to achieve smart cities with ZEBs if the related aspects of ZEB are fulfilled. Aksamija [12] discussed the potential of retrofitting a commercial building to achieve net zero energy goal and presented that simulation and energy modelling are beneficial tools for retrofitting as they can help us analysing the energy saving measures for their energy saving potential. Ballarini et al. [13] assessed the globally accepted refurbishment scenarios for transforming buildings to Net-ZEB and said that remarkable results could be obtained from retrofit measures by optimizing the retrofitting procedures for adequate daylight delivery which also improves the visual comfort. Feng et al. [14] analysed the performance of 34 case study NZEBs in hot and humid climate and found that some of the buildings demonstrated annual energy use to be less than $100 \mathrm{KWh} / \mathrm{m}^{2}$ and some generated surplus energy that can be sold out to the grid. The study also confirmed that with a reasonable amount of renewable energy sources the building can achieve NZEB status. Kaewunruen et al. [15] concluded that if the existing buildings are retrofitted to be net zero energy buildings (NZEB) and same practices are implemented for the future constructions, society's overall carbon footprint levels can be reduced substantially. Aksamija [16] studied the retrofitting feasibility of the existing commercial building and presented that by applying passive design strategies such as day-lighting, improvement in building envelope and by the effective use of renewable energy sources the goal of Net Zero Energy in commercial building is achievable. Ferreira et al. [17] studied the cost-effective solutions for net zero energy by analysing a building in Portugal and concluded that nearly zero energy building with lowest cost is achievable if renewables with cost optimal levels are introduced. Ferrari and Beccali [18] studied strategies for retrofitting to improve energy performance of public building. The 
study concluded that the cost of energy and discount rate are the main parameters to affect the economic performance of retrofit solution.

Florides et al. [19] carried out research on the different measures to lessen the buildings energy consumption and conferred that among all the elements of the building envelope, roof plays the most important role in cutting down the energy consumption. Pylpudi et al. [20] applied the energy efficient measures in combination with the renewable resources in their simulation-based study on a building of a university campus. They concluded that the best productive period for the PV panels is from March to September for the study area. Albadry et al. [21] analysed the existing buildings in Egypt to achieve net zero energy through retrofitting and found that it affordable to use photo voltaic panels and materials available in market for retrofitting. Zubair et al. [22] analysed the renewable energy systems for forming a net zero energy building and presented that the on-site solar energy system has made it possible for a building to be independent of the national grid. Also with the shade provided by solar panels on the roof top, the energy load of the building can be reduced. Gallo et al. [23] analysed the NZEB in Spain by integrating photovoltaic and conferred that it can cover almost the whole energy demand of zero energy building and is more efficient in the areas with higher solar radiation availability. It's also been conferred that the integration of PV in NZEB remains feasible due to economical production of PV panels. Tariku and Iffa [24] studied the effect of insulation thickness in the attic and found that the thicker insulation provides more cooling benefits during summer. Piselli et al. [25] presented the role of thermal insulation and conferred that buildings energy performance is greatly affected by varying insulation implemented to a standard roof without any external coating. Brito Filho and Santos [26] studied the thermal performance of the roofs in subtropical climates with thermal insulation installed and conferred that the thermal insulation layer in the roof is the best energy saving option. Garshasni et al. [27] adopted a simulation approach to analyse the energy consumption of NZEB on hourly basis and found that 60-100\% of energy produced by renewable energy sources is consumed by the NZEB and up to $40 \%$ of the energy is transferred back to the grid. Nguyen et al. [28] carried out a simulation-based study by applying different optimization strategies to a building and approved that this approach of optimization can be effective to explore various cost optimal design strategies by taking least computing time. Ahmad et al. [29] carried out the simulation-based study and estimated the energy consumption of a residential building after applying the energy efficient measure to windows, HVAC and space lightening for a two storied building with a payback period of three years. Volk et al. [30] reviewed over 180 research papers from past and concluded that the usage of BIM in existing buildings is quite rare that that of the newly constructed structures. The study emphasized the implementation of BIM in existing structures as it presents numerous advantages related to cost and sustainability requirements and also the energy performance of building is essential to predict in order to make the design of buildings more energy efficient with enhanced indoor environment at reasonable cost. Ma et al. [31] reviewed the computational optimization methods for different fields of building design and presented that companies are realizing the importance of computational optimization due to effectiveness of such methods. The study also confirms that Building Information Management (BIM) will help integrating every aspect of the building design. Oti and Abanda [32] reviewed information modelling systems i.e. BIM, GIS, CEIM, in the key sectors of built environment. The study concluded that different information modelling systems can be incorporated in building sector for different purposes in order to improve efficiency and productivity of all the works involved in the process. Keskin and Salman [33] also reported the retrofitting process on mega airport project improved by implementing BIM for energy analysis. Wang et al. [34] conducted a simulation-based study on a case building and achieved 
Zero-Energy by utilizing parking lots and $15 \%$ of rooftop area for PV panels installation with a payback period of 4.3 years. Alajmi et al. [35] examined three different scenarios for achieving net zero energy of existing building and reported that the payback period for EEMs (Energy Efficient Measures) ranges from 0.5 years to 3 years and for solar systems it ranges from 14.1 to 16.1 years making EEMs more cost efficient than solar systems. Wells et al. [36] explored the existing NZEB models in Australian context and emphasized on the government policies to encourage Net Zero Energy targets. The study enlightens the lack of research for auditing the embodied energy of the materials and devices required for the on-site energy generation. The study also suggests to discuss the economic feasibility of NZEB as there is a little research on this factor.

In order to transform the already existing conventional building to NZEB those parameters need to be considered that will emphasize on the greater efficiency with ample productivity. One big factor in such transformation is the extra cost for materials and putting them to function as required i.e. solar panels installation, enhancing the building envelope, improving the daylight etc. In such conditions the net zero energy concept will contribute a lot to overcome the energy scarcity. In the light of above, it can be concluded that NZEB offer a promising aspect to manage the energy crises in construction, specifically in building sector. However, the application to the existing buildings seems limited by certain barriers. These may include the climatic conditions, the parameters incorporated, possibility level of retrofitting in existing structures and cost concerns for such endeavours.

\section{Methodology}

Case Study strategy was adopted to carry out the study. Four commercial buildings were selected from capital city, Table 1.

\section{TABLE 1. SumMARY OF THE SELECTED BUILDINGS}

\begin{tabular}{lll}
\hline Building Code & Area, $\mathrm{m}^{2}$ & No of Story \\
\hline BLDG-1 & 1746 & $\mathrm{G}+3$ \\
BLDG-2 & 1013 & $\mathrm{G}+3$ \\
BLDG-3 & 1115 & $\mathrm{G}+4$ \\
BLDG-4 & 3110 & $\mathrm{G}+4$ \\
\hline
\end{tabular}

Primary data included construction drawings and bill of quantities (B.O.Qs) from the concerned organizations. Digital modelling was performed and 3D models were created for all the case studies using AUTODESK REVIT, software. These architectural 3D models were transformed to energy models using Insight360. The Building Energy Model (BEM) were generated from the architectural 3D model of the specific building. This energy model allowed to examine the model elements. The energy analysis was performed by considering the NZEB factors and their parameters as shown in the Table 2.

TABle 2. SElected Factors And AdAPted Parameters

\begin{tabular}{ll}
\hline Factors & Adapted Parameters \\
\hline Roof insulation & R38, R60 \\
PV-Surface Coverage & $0 \%, 60 \%, 75 \%, 90 \%$ \\
Panel Efficiency & $20.4 \%$ \\
\hline
\end{tabular}

Expanded Polystyrene was opted as roof insulation. Two types, R38 (178 mm thick) and R60 (280 mm thick), locally available were considered. Horvath [37] studied the material 
properties of the EPS and found that expanded polystyrene has the ability to be used for thermal insulation due to its closed cell structure. Similarly, Dombayc1, et al. [38] carried out a optimization based study on this thickness of insulation for walls and found expanded polystyrene as optimal insulation material. In case of PVs, each plate has a power of $445 \mathrm{~W}$ and area of $28 \mathrm{ft}^{2}\left(2.6 \mathrm{~m}^{2}\right)$. The factor Panel Efficiency was considered to be $20.4 \%$. The energy analysis has been performed in four phases with different parameters of the considered NZEB factors, Table 3.

Table 3. Phases of Energy Analysis and Their Respective Parameters

\begin{tabular}{llll}
\hline Phases & $\begin{array}{l}\text { Adapted PV coverage, } \\
\% \text { of roof area }\end{array}$ & Roof Insulation & Panel efficiency, \% \\
\hline Phase-I & $0 \%$ & Uninsulated & N.A \\
Phase-II & $0 \%$ & R38, R60 & N.A \\
Phase-III & $60 \%, 75 \%, 90 \%$ & Uninsulated & 20.4 \\
Phase-IV & $60 \%$ & R38 & 20.4 \\
\hline
\end{tabular}

In order to perceive the effectiveness of the NZEB factors, a comparison was performed on the basis Conventional versus Proposed Insulation, Conventional versus Proposed Surface Coverage. It determined the improvement in the energy performance, and evaluating different parameters for optimized solution. This helped the designers to have an idea about the energy performance of the building during the design stage in virtual reality. This allows them to make the necessary modifications to the building in order to make it more energy efficient and improve the energy performance of a particular building. The cost analysis process included impact of Roof Insulation, cost of the buildings after PV Installation and a comparison of cost of conventional buildings with the cost of the building innovated NZEB. Based upon the results of different phases, the payback period estimated was for the most efficient and optimum parameters NZEB solution.

\section{REsults}

The energy patterns of the building's models were studied from their respective energy models. In each phase, the energy use intensity (EUI) value was obtained for each building model. Fig. 1 elaborates the adopted energy analysis cycle for the current study.

\subsection{Energy Analysis}

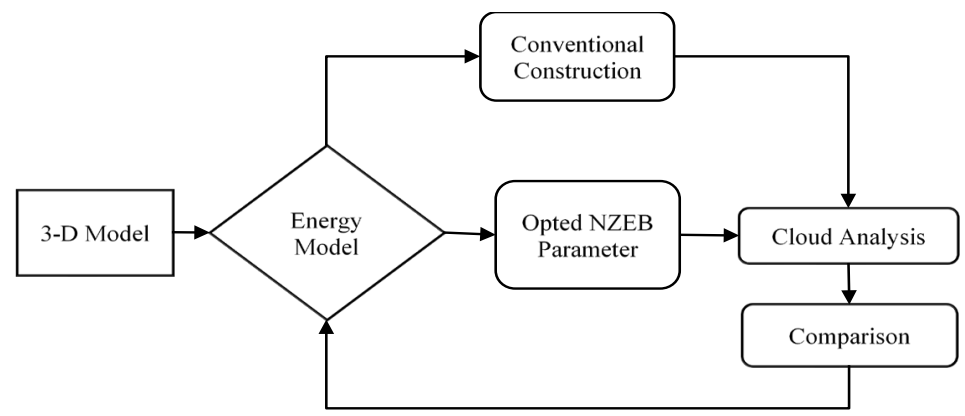

Fig. 1. Energy Analysis Cycle. 


\subsubsection{Phase-I}

In this phase, the selected case study buildings were analysed without considering the selected NZEB factors. In other words, the buildings were supposed to be conventional. In conventional construction, the PV-Surface Coverage was set to $0 \%$, which means no solar panels installed on the roof. Similarly, Roof Construction has been set to uninsulated, Fig. 2. Based upon the conventional settings, including heating, cooling and lighting, the annual energy consumptions achieved for the buildings have been summarised in Table 4.

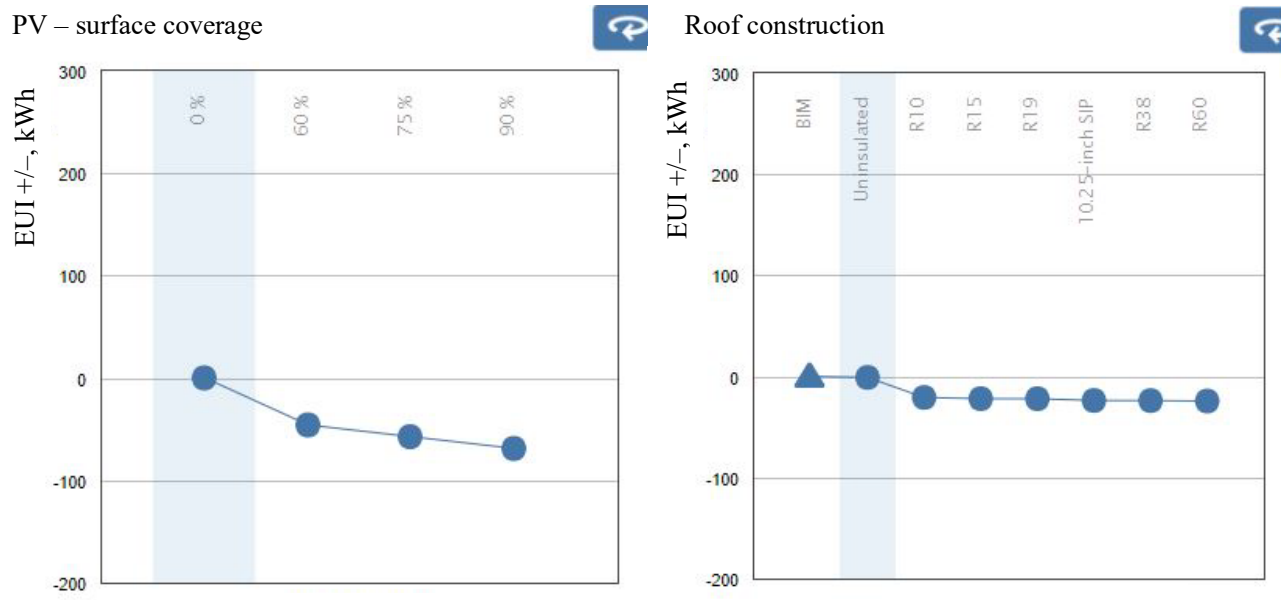

Fig. 2. Parameters for Surface Coverage and Roof Construction for Energy intensity, EUI (kWh).

The analysis also indicated the ASHRAE 90.1 results which is standard established benchmark for commercial building energy codes and provides the minimum requirements for energy-efficient design [39].

TABLE 4. ENERGY ANALYSIS - CONVENTIONAL CONS
\begin{tabular}{lll} 
Case Study & $\begin{array}{l}\text { Energy Usage, } \\
\mathrm{kWh} / \mathrm{m}^{2} / \mathrm{yr}\end{array}$ & $\begin{array}{l}\text { ASHRAE } 90.1, \\
\mathrm{kWh} / \mathrm{m}^{2} / \mathrm{yr}\end{array}$ \\
\hline BLDG-1 & 491 & 689 \\
BLDG-2 & 483 & 664 \\
BLDG-3 & 563 & 787 \\
BLDG-4 & 310 & 426 \\
\hline
\end{tabular}

\subsubsection{Phase-II}

In this phase of energy analysis, only Roof Insulation was considered. The energy analysis was carried out for two types of insulations i.e., R38 and R60 as shown in the Fig. 3. 

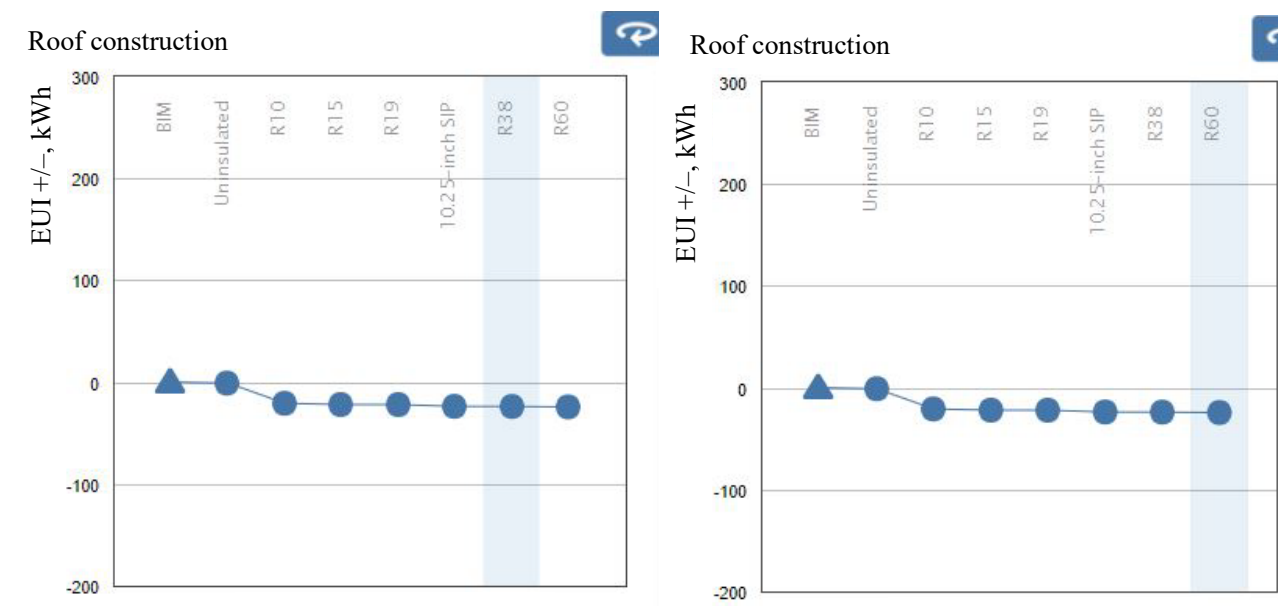

Fig. 3. Insight energy setting showing parameters for roof construction (R38 and R60).

The factor PV-Surface Coverage was set to $0 \%$. The results obtained are presented for each case study building in the Table 5 below.

TABle 5. Energy ANALysis - Phase-II

\begin{tabular}{llllll}
\hline \multirow{2}{*}{ Case Study } & \multirow{2}{*}{$\begin{array}{l}\text { Uninsulated, } \\
\mathrm{kWh} / \mathrm{m}^{2} / \mathrm{yr}\end{array}$} & \multirow{2}{*}{$\begin{array}{l}\mathrm{R} 38 \text { Insulation, } \\
\mathrm{kWh} / \mathrm{m}^{2} / \mathrm{yr}\end{array}$} & $\begin{array}{l}\mathrm{R} 60 \text { Insulation, } \\
\mathrm{kWh} / \mathrm{m}^{2} / \mathrm{yr}\end{array}$ & \multicolumn{2}{c}{ Difference to Uninsulated, \% } \\
\cline { 6 - 7 } & & 471 & 470 & $\mathrm{R} 38$ & $\mathrm{R} 60$ \\
\hline BLDG-1 & 491 & 462 & 461 & 4.07 & 4.2 \\
BLDG-2 & 483 & 556 & 556 & 1.25 & 4.5 \\
BLDG-3 & 563 & 307 & 307 & 0.96 & 1.25 \\
BLDG-4 & 310 & &
\end{tabular}

A reduction in the annual energy usage of the buildings was observed with both type of insulation with a minor difference.

\subsubsection{Phase-II}

In this phase of energy analysis, the factor PV-Surface Coverage was considered. In this phase $60 \%, 75 \%$ and $90 \%$ options were selected and analysed, Fig. 4. 

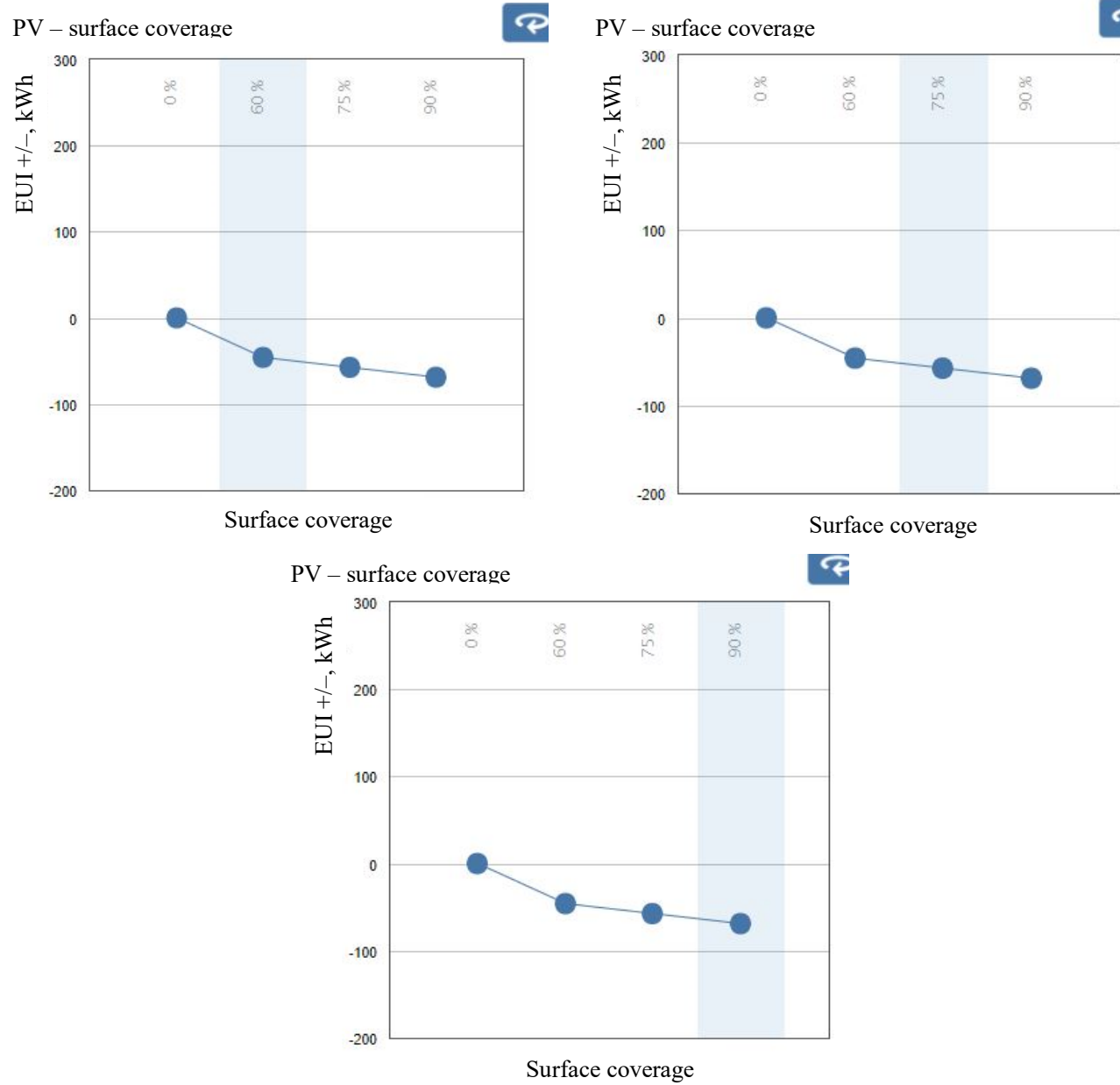

Fig. 4. Insight parameters for PV Surface coverage of $60 \%, 75 \%$ and $90 \%$ for Phase-III.

The results of energy analysis Phase-III are presented in Table 6.

TABLE 6. ENERGY ANALYSIS - PHASE-III

\begin{tabular}{|c|c|c|c|c|c|c|c|}
\hline \multirow[t]{2}{*}{$\begin{array}{l}\text { Case } \\
\text { Study }\end{array}$} & \multirow{2}{*}{$\begin{array}{l}0 \% \text { Surface } \\
\text { coverage, } \\
\mathrm{kWh} / \mathrm{m}^{2} / \mathrm{yr}\end{array}$} & \multirow{2}{*}{$\begin{array}{l}60 \% \text { Surface } \\
\text { coverage, } \\
\mathrm{kWh} / \mathrm{m}^{2} / \mathrm{yr}\end{array}$} & \multirow{2}{*}{$\begin{array}{l}75 \% \text { Surface } \\
\text { coverage, } \\
\mathrm{kWh} / \mathrm{m}^{2} / \mathrm{yr}\end{array}$} & \multirow{2}{*}{$\begin{array}{l}90 \% \text { Surface } \\
\text { coverage, } \\
\mathrm{kWh} / \mathrm{m}^{2} / \mathrm{yr}\end{array}$} & \multicolumn{3}{|c|}{$\begin{array}{l}\text { Variation w.r.t } 0 \% \\
\text { surface coverage, } \%\end{array}$} \\
\hline & & & & & $60 \%$ & $75 \%$ & $90 \%$ \\
\hline BLDG-1 & 491 & 483 & 481 & 479 & 1.62 & 2.0 & 2.4 \\
\hline BLDG-2 & 483 & 475 & 473 & 471 & 1.65 & 2.0 & 2.5 \\
\hline BLDG-3 & 563 & 556 & 554 & 552 & 1.24 & 1.6 & 1.95 \\
\hline BLDG-4 & 310 & 303 & 301 & 300 & 2.25 & 2.9 & 3.2 \\
\hline
\end{tabular}

From the above results it is evident that the most energy efficient results were obtained with $60 \%$ roof top surface coverage. With $75 \%$ and $90 \%$ surface coverages the results were not impressive as the energy usage reduced by very small amount and also the cost for larger areas is more. Hence the most efficient option was selected to be $60 \%$. Before moving to the 
fourth phase of energy analysis, it was necessary to ascertain the parameters for the selected factors. In above energy analyses results, the performance of each parameter was examined. The cost of implication of these parameters was also necessary to be determined. The ones with minimum cost were chosen for the fourth phase of energy analysis. In order to select the insulation material for roofs of case studies on the bases of $R$ values, the costing of both R38 and R60 type insulation was carried out to see which type of insulation will be more economical to be used in this study. Table 7 provides the basis for cost analysis of roof insulation with varying thickness based upon the local market.

TABLE 7. COST OF INSULATION

\begin{tabular}{lll}
\hline Type of Insulation & Required Thickness, mm & Cost per $\mathrm{m}^{2}$, USD \\
\hline R38 & 178 & 14.26 \\
R60 & 280 & 22.4 \\
\hline
\end{tabular}

The cost of solar panels installation for opted percentages of roof top surfaces was carried out to find out the most economical and energy efficient option, Table 8 . In third phase of energy analysis, it was confirmed that the difference between the energy results of $60 \%$ and $75 \%, 90 \%$ option was minimal also the cost for $60 \%$ will be lesser than the rest of the options. Hence $60 \%$ option was considered for the rest of the analysis.

TABLE 8. PERCENTAGE INCREASE IN COST FOR PV INSTALLATION

\begin{tabular}{llll}
\hline Case Studies & $60 \%$ & $75 \%$ & $90 \%$ \\
\hline BLDG-1 & 7.3 & 9.24 & 10.89 \\
BLDG-2 & 9.3 & 11.67 & 14.00 \\
BLDG-3 & 12.5 & 14.84 & 17.96 \\
BLDG-4 & 13.38 & 16.64 & 19.90 \\
\hline
\end{tabular}

\subsubsection{Phase-IV}

This phase of energy analysis was carried out by considering both the NZEB factors and were applied to the models. In Roof Construction factor, R38 type insulation was selected for each case study. When the cost analysis was done the R38 type insulation was found to be cheaper than R60 due to its less thickness. The factor PV-Surface Coverage was set to $60 \%$ as from the results of energy analysis in Phase-III it was evident that the $60 \%$ coverage of roof surface with solar panels provides maximum energy and cost efficiency because the difference between the results of $60 \%, 75 \%$ and $90 \%$ was minimal and also $60 \%$ option required lesser additional cost of installation. Table 9 shows the energy usage of each case study building during Phase-IV of energy analysis and also the difference between the PhaseI (Conventional) and Phase-IV (Innovated NZEB) is also presented.

TABle 9. Results of Fourth Phase of ENERgy ANALysis, R38 AND 60 \% PV COVERAGE

\begin{tabular}{lllll}
\hline $\begin{array}{l}\text { Case } \\
\text { Study }\end{array}$ & $\begin{array}{l}\text { Energy Usage of conventional } \\
\text { model, } \mathrm{kWh} / \mathrm{m}^{2} / \mathrm{yr}\end{array}$ & $\begin{array}{l}\text { Energy usage of innovated } \\
\text { NZEB }, \mathrm{kWh} / \mathrm{m}^{2} / \mathrm{yr}\end{array}$ & $\begin{array}{l}\text { Difference, } \\
\mathrm{kWh} / \mathrm{m}^{2} / \mathrm{yr}\end{array}$ & $\begin{array}{l}\text { Percentage } \\
\text { Decrease, \% }\end{array}$ \\
\hline BLDG-1 & 491 & 463 & 28 & 5.7 \\
BLDG-2 & 483 & 453 & 30 & 6.2 \\
BLDG-3 & 563 & 549 & 14 & 2.5 \\
BLDG-4 & 310 & 299 & 11 & 3.5 \\
\hline
\end{tabular}


The energy usage by BLDG-1 during four phases is shown in Fig. 5. It has been observed the annual energy usage of the building reduced by $20 \mathrm{kWh} / \mathrm{m}^{2} / \mathrm{yr}$ which was more than that of the Phase-III where the energy usage reduced by $8 \mathrm{kWh} / \mathrm{m}^{2} / \mathrm{yr}$. The Roof Construction factor remained dominant than the PV-Surface Coverage in terms of energy efficiency. The combined application of both the factors reduced the energy usage of BLDG-1 by $5.7 \%$.

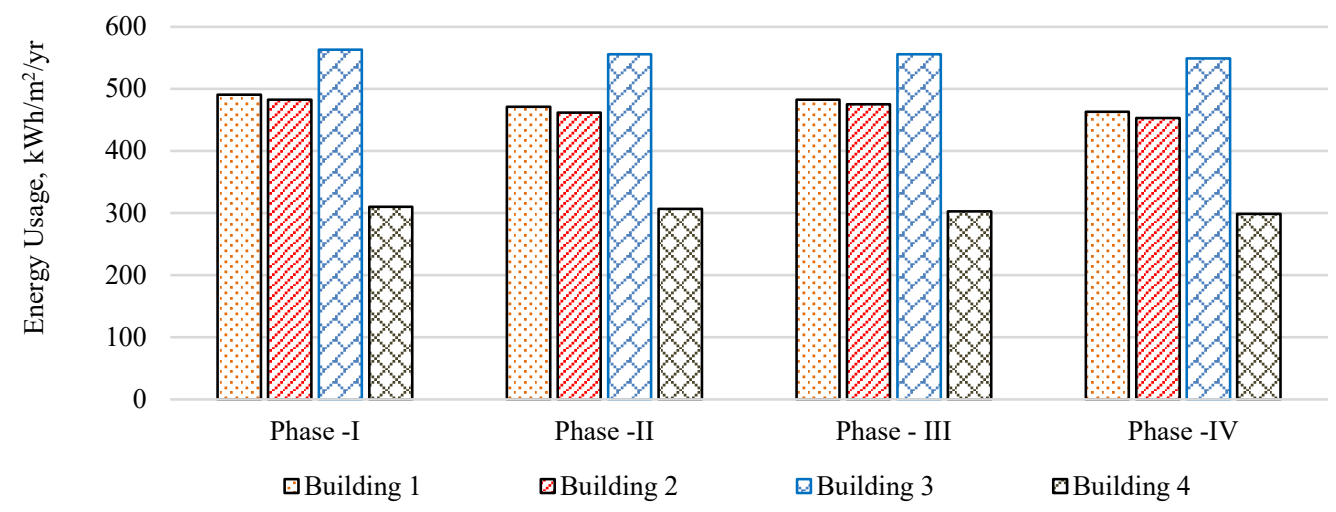

Fig. 5. Energy Usage for each phase of energy analysis.

For BLDG-2, only R38 type insulation was considered in Phase-II. This resulted in a saving of almost $4.5 \%$. However, application of $60 \%$ roof coverage with PV surface reduced the energy by $1.5 \%$ on annual basis. In this case also the Roof Insulation factor is more dominant than the PV-Surface Coverage. The combined application resulted in a saving of $30 \mathrm{kWh} / \mathrm{m}^{2} / \mathrm{yr}$.

However, for BLDG-3, on individual basis both Phases-II and III resulted in an equal saving in terms of energy patterns. The combined application of both the factors reduced the energy usage of BLDG-3 by $14 \mathrm{kWh} / \mathrm{m}^{2} / \mathrm{yr}$. In case of BLDG-4 building, R38 type insulation was considered with PV-Surface Coverage of $60 \%$. The annual energy usage of the building reduced by $3 \mathrm{kWh} / \mathrm{m}^{2} / \mathrm{yr}$ and $7 \mathrm{kWh} / \mathrm{m}^{2} / \mathrm{yr}$. PV-Surface Coverage has been dominant in energy efficiency. On overall, energy usage decreased by $11 \mathrm{kWh} / \mathrm{m}^{2} / \mathrm{yr}$.

\subsection{Cost Analysis}

The cost analysis of the NZEB transformation is one of the most important concerns in this study. Hence a detailed cost analysis was carried out for the parameters of NZEB factors that were finalized for this study. The average cost was taken due to variation in the cost of installation depending on the location of the site. The main objective of this study is to determine the cost of implementing the most suitable and efficient combination of factors and their parameters. The cost analysis process was done in four steps:

1. Without implementing any NZEB factor (conventional building);

2. With R38 type Insulation;

3. With $60 \%$ of the roof top covered with PV panels;

4. With both R38 insulation and $60 \%$ of roof top covered with PV panels.

The cost of conventional buildings was determined by the Bill of Quantities (BOQs) of the respective buildings which was set as a baseline. The cost of roof insulation material and its installation was determined was based upon the market rates in Phase-II. Expanded Polystyrene was selected as insulation material due to its availability and effectiveness in the sub-tropical climate of location of case studies. Since, in third phase, the $60 \%$ installation of 
$\mathrm{PV}$ resulted in the most efficient results hence the cost analysis for all the case study buildings was based on this surface coverage option. The additional cost of installing PV panels on each case study building was calculated. In fourth phase of energy analysis, both the factors were analysed for each case study building. The total cost of the buildings after applying NZEB adopted factors was analysed for each of the phase against the energy savings achieved. A comparison in Table 10, was done to represent the rise in cost with the addition of each factor.

TABle 10. Summary of Phase Wise ENERgy AND Cost COMPARISON

\begin{tabular}{lcccccc}
\hline \multirow{2}{*}{ Case Study } & \multicolumn{3}{c}{ Energy Saving, \% } & \multicolumn{3}{c}{ Additional Cost, \% of conventional } \\
& Phase-II & Phase-III & Phase-IV & Phase-II & Phase-III & Phase-IV \\
\hline BLDG-1 & 4.07 & 1.63 & 5.70 & 1.56 & 7.29 & 8.85 \\
BLDG-2 & 3.87 & 1.63 & 6.11 & 1.99 & 9.32 & 11.32 \\
BLDG-3 & 1.43 & 1.43 & 2.85 & 2.54 & 12.48 & 15.02 \\
BLDG-4 & 0.61 & 1.43 & 2.24 & 2.88 & 13.37 & 16.25 \\
\hline
\end{tabular}

From the energy analysis of the case studies and the cost analysis of the energy reduced and the components opted for NZEB factors, the payback periods of the additional investment were established. The calculation was based upon the cost of commercial electricity unit being charged by the government officially. It has been learned that the additional cost incurred for the transformation of conventional building into NZEB building can easily be recovered in 4 to 5 years in most of cases. This would not only result in sustainable energy consumptions patterns but also easy recovery of expense by producing clean energy and avoiding grid source. Thus, it is very vital to educate the stakeholders; owners, residents, designers, that conventional building can easily result in energy saving facilities.

\section{Conclusions}

The buildings, especially in developing countries, built by conventional methods are mainly based on cost-oriented techniques without any considerations to energy consumption patterns. However, with increasing population and urbanization patterns around the world, the energy crises are becoming serious concerns. The current research explores the opportunity of transforming a conventional commercial building to NZEB. The NZEB factors were incorporated in $3 \mathrm{D}$ virtually developed case study models using BIM. The BIM models were transformed to Energy models for further analysis through cloud computing. Based upon the local conditions, only roof construction and PV-Surface Coverage were selected from the range of other NZEB factors. The simulations were run and the most efficient ones were chosen. The study observed that the incorporation of Roof Insulation (R38) and PV panels on the $60 \%$ roof top area reduced the annual energy usage. This resulted in cost increase with both factors for BLDG-1, BLDG-2, BLDG-3 and BLDG-4 from $9 \%$ to $16 \%$. However, the energy saving achieved from incorporating NZEB parameters helped to recover the additional expense with payback periods of $3.5,4.5,4$, and 9 years for BLDG-1, BLDG-2, BLDG-3 and BLDG-4 respectively. The study has been limited to the incorporation of only two NZEB parameters keeping in view the existing buildings and local market conditions, in other words partial NZEB. The results were positive and future studies are advised to implement the full transformation concept for more encouraging results, especially in new planned buildings according to the requirements of the certain location. 


\section{REFERENCES}

[1] Esin T., Yüksek I. Sustainable resource utilisation in the production of building materials. International Journal of Sustainable Building Technology and Urban Development 2013:4(2):141-145. https://doi.org/10.1080/2093761X.2013.768186

[2] International Energy Agency. World Energy Outlook 2021. Paris: IEA, 2021.

[3] Cao X., Dai X., Liu J. Building energy-consumption status worldwide and the state-of-the-art technologies for zeroenergy buildings during the past decade. Energy and buildings 2016:128:198-213. https://doi.org/10.1016/j.enbuild.2016.06.089

[4] Santamouris M. Cooling the buildings-past, present and future. Energy and Buildings 2016:128:617-638. https://doi.org/10.1016/j.enbuild.2016.07.034

[5] International Energy Agency. Global Energy Review 2019: The latest trends in energy and emissions in 2019. Paris: IEA, 2020.

[6] World bank. Total greenhouse gas emissions (kt of CO2 equivalent) [Online]. [Accessed 27.11.2021]. Available: https://data.worldbank.org/indicator/EN.ATM.GHGT.KT.CE

[7] de Oliveira J. A. P., et al. Promoting win-win situations in climate change mitigation, local environmental quality and development in Asian cities through co-benefits. Journal of Cleaner Production 2013:58:1-6. https://doi.org/10.1016/j.jclepro.2013.08.011

[8] Torcellini P., et al. Zero energy buildings: a critical look at the definition. United States, 2006.

[9] Nejat P., et al. A global review of energy consumption, $\mathrm{CO}_{2}$ emissions and policy in the residential sector (with an overview of the top ten $\mathrm{CO}_{2}$ emitting countries). Renewable and Sustainable Energy Reviews 2015:43:843-862. https://doi.org/10.1016/j.rser.2014.11.066

[10] de Rubeis T., et al. Is a self-sufficient building energy efficient? Lesson learned from a case study in Mediterranean climate. Applied Energy 2018:218:131-145. https://doi.org/10.1016/j.apenergy.2018.02.166

[11] Kylili A., Fokaides P. A. European smart cities: The role of zero energy buildings. Sustainable Cities and Society 2015:15:86-95. https://doi.org/10.1016/j.scs.2014.12.003

[12] Aksamija A. Regenerative design and adaptive reuse of existing commercial buildings for net-zero energy use. Sustainable cities and society 2016:27:185-195. https://doi.org/10.1016/j.scs.2016.06.026

[13] Ballarini I., et al. Transformation of an office building into a nearly zero energy building (nZEB): Implications for thermal and visual comfort and energy performance. Energies 2019:12(5):895. https://doi.org/10.3390/en12050895

[14] Feng W., et al. A review of net zero energy buildings in hot and humid climates: Experience learned from 34 case study buildings. Renewable and Sustainable Energy Reviews 2019:114:109303. https://doi.org/10.1016/j.rser.2019.109303

[15] Kaewunruen S., Rungskunroch P., Welsh J. A digital-twin evaluation of net zero energy building for existing buildings. Sustainability 2019:11(1):159. https://doi.org/10.3390/su11010159

[16] Aksamija A. Regenerative design of existing buildings for net-zero energy use. Procedia Engineering 2015:118:72-80. https://doi.org/10.1016/j.proeng.2015.08.405

[17] Ferreira M., et al. Comparing cost-optimal and net-zero energy targets in building retrofit. Building Research \& Information 2016:44(2):118-201. https://doi.org/10.1080/09613218.2014.975412

[18] Ferrari S., Beccali M. Energy-environmental and cost assessment of a set of strategies for retrofitting a public building toward nearly zero-energy building target. Sustainable Cities and Society 2017:32:226-234. https://doi.org/10.1016/j.scs.2017.03.010

[19] Florides G. A., et al. Measures used to lower building energy consumption and their cost effectiveness. Applied Energy 2002:73(3-4):299-328. https://doi.org/10.1016/S0306-2619(02)00119-8

[20] Pyloudi E., Papantoniou S., Kolokotsa D. Retrofitting an office building towards a net zero energy building. Advances in Building Energy Research 2015:9(1):20-33. https://doi.org/10.1080/17512549.2014.917985

[21] Albadry S., Tarabieh K., Sewilam H. Achieving net zero-energy buildings through retrofitting existing residential buildings using PV panels. Energy Procedia 2017:115:195-204. https://doi.org/10.1016/j.egypro.2017.05.018

[22] Zubair M., et al. NPC based design optimization for a net zero office building in hot climates with PV panels as shading device. Energies 2018:11(6):1391. https://doi.org/10.3390/en11061391

[23] Gallo A., et al. Analysis of net Zero-Energy Building in Spain. Integration of PV, solar domestic hot water and airconditioning systems. Energy Procedia 204:48:828-836. https://doi.org/10.1016/j.egypro.2014.02.096

[24] Tariku F., Iffa E. Effect of attic insulation thickness and solar gain in a mild climate. Energy Procedia 2015:78:67-72. https://doi.org/10.1016/j.egypro.2015.11.116

[25] Piselli C., et al. Cool roof impact on building energy need: The role of thermal insulation with varying climate conditions. Energies 2019:12(17):3354. https://doi.org/10.3390/en12173354

[26] Brito Filho J., Santos T. O. Thermal analysis of roofs with thermal insulation layer and reflective coatings in subtropical and equatorial climate regions in Brazil. Energy and Buildings 2014:84:466-474. https://doi.org/10.1016/j.enbuild.2014.08.042

[27] Garshasbi S., Kurnitski J., Mohammadi Y. A hybrid Genetic Algorithm and Monte Carlo simulation approach to predict hourly energy consumption and generation by a cluster of Net Zero Energy Buildings. Applied Energy 2016:179:626637. https://doi.org/10.1016/j.apenergy.2016.07.033 
[28] Nguyen A.-T., Reiter S., Rigo P. A review on simulation-based optimization methods applied to building performance analysis. Applied Energy 2014:113:1043-1058. https://doi.org/10.1016/j.apenergy.2013.08.061

[29] Ahmad K., Rafique A. F., Badshah S. Energy efficient residential buildings in Pakistan. Energy \& Environment 2014:25(5):991-1002. https://doi.org/10.1260/0958-305X.25.5.991

[30] Volk R., Stengel J., Schultmann F. Building Information Modeling (BIM) for existing buildings-Literature review and future needs. Automation in Construction 2014:38:109-127. https://doi.org/10.1016/j.autcon.2013.10.023

[31] Ma Z., et al. Existing building retrofits: Methodology and state-of-the-art. Energy and Buildings 2012:55:889-902. https://doi.org/10.1016/j.enbuild.2012.08.018

[32] Oti A. H., Abanda F. H. A review of information modelling systems in the built environment. In Adjallah K., Birregah B., Abanda H. (eds) Data-Driven Modeling for Sustainable Engineering. ICEASSM 2017. Lecture Notes in Networks and Systems, 2019:72:161-174. https://doi.org/10.1007/978-3-030-13697-0 12

[33] Keskin B., Salman B. Building Information Modeling (BIM) Implementation for Sustainability Analysis: A Mega Airport Project Case Study. Proceedings of the $7^{\text {th }}$ International Building Physics Conference 2018. https://doi.org/10.14305/ibpc.2018.ps10

[34] Wang D., et al. Assessment of the potential of high-performance buildings to achieve zero energy: A case study. Applied Sciences 2019:9(4):775. https://doi.org/10.3390/app9040775

[35] Alajmi A., Abou-Ziyan H., Ghoneim A. Achieving annual and monthly net-zero energy of existing building in hot climate. Applied Energy 2016:165:511-521. https://doi.org/10.1016/j.apenergy.2015.11.073

[36] Wells L., Rismanchi B., Aye L. A review of Net Zero Energy Buildings with reflections on the Australian context. Energy and Buildings 2018:158:616-628. https://doi.org/10.1016/j.enbuild.2017.10.055

[37] Horvath J. J. Expanded polystyrene (EPS) geofoam: An introduction to material behaviour. Geotextiles and Geomembranes 1994:13(4):263-280. https://doi.org/10.1016/0266-1144(94)90048-5

[38] Dombaycı Ö. A., Gölcü M., Pancar Y. J. A. E. Optimization of insulation thickness for external walls using different energy-sources. 2006:83(9):921-928. https://doi.org/10.1016/j.apenergy.2005.10.006

[39] Chan A. L. S. Evaluating the impact of photovoltaic systems on the thermal performance of buildings and its implication to building energy code. A case study in subtropical Hong Kong. Energy Policy 2018:119:674-688. https://doi.org/10.1016/j.enpol.2018.04.041 